\title{
The Value of Listening and Affective Factors in Managing People in 4.0
}

\author{
Julia Eka Rini* \\ Faculty of Languages and Literature, Petra Christian University, Jl. Siwalankerto 121-131, \\ Surabaya 60236, Indonesia.
}

\begin{abstract}
In an era where people are bombarded with continuous streams of information, it is now difficult to differentiate which news is true and which one is a hoax, which actually manipulates affective factors to manage people to believe it. This situation brings about two points that are worth paying attention to in dealing with people. First, with the quick spread of abundant information, it is as if people are forced to listen to anything these days and, therefore, lack of being listened to. Second, if affective factors are so easily manipulated for negative purposes, they can surely be cultivated for good purposes also. Therefore, listening and paying attention to affective factors in managing people could be the usual strategy to achieve an unusual result. This paper would give examples of what a teacher can do in a classroom or a manager in a company.
\end{abstract}

Keywords: Good purpose, maximum result, people-oriented, positive, process.

\section{Introduction}

When the writer was young, people always told the writer that an important decision should not be made based on emotion and feelings and that relying on such a decision was not encouraged. Nowadays, this piece of advice is important to consider since emotions or feelings play an important role in the course of daily lives. An everyday example of forwarding a WhatsApp message due to feeling pity, anger, or other emotional reasons without rechecking is not something unfamiliar to most people having gadgets. The fact is that emotion and feelings are the ones that are played in the era of the internet of things for negative purposes. Feelings and emotional states are being used in the internet world to create commotion, fear, anxiety, and insecurity [1]. If they can drive people to do negative things, then they can be targeted for something positive, especially in managing people.

\section{Methods}

The students observed were ten students of English Departments where the writer was teaching. All of the ten students had taken Speaking 3, and in the time the observation was done, the ten students repeated the same class. Before the semester started, the writer made

\footnotetext{
*Corresponding author: jerini@petra.ac.id
} 
an effort to obtain some information from the lecturers who taught the class previously about the ten students. After getting the information about the students, in the first week of the semester, at the introduction session, the writer, who was also the lecturer of the class, made the students talk about their motivation in studying in the English Department. Throughout the semester, none of the ten students missed any of the sixteen meetings in that semester; the ten students attended all the sessions in Speaking 3. At the end of the semester, the writer as the lecturer of the Speaking 3 class and another lecturer who was not teaching the class gave the Speaking examination to the ten students, and both lecturers agreed that all of the ten students could pass the Speaking 3 class.

\section{Discussion}

The discussion below covers three points, namely: affective factors, managing people, and listening.

\subsection{Affective factors}

In line with the writer's profession, the definition of affective factors and the people observed were mainly from the area of teaching. Lightbown and Spada explain Krashen's definition of affective factors as something to do with 'feeling, motives, needs, attitudes, and emotional states [2]. Not all language experts believe in Krashen's affective factors; however, teachers, who deal directly with students, believe what Krashen says about affective factors. According to teachers, students seem unable to concentrate and, therefore, do not learn a lot in the classroom if they are anxious, sad, have problems, etc. From this, it can be concluded that affective factors, especially feelings and emotional states, influence everyday life.

In the era of the internet of things, where everything is connected to the internet, whether we realize it or not, affective factors are the ones that are expressed or even manipulated by people. Lots of examples can be found in social media accounts. When one person cannot scold another in person, s/he does it through Facebook or other social media. When employees are not satisfied with their companies, they often use social media to express dislikes and dissatisfaction or weaknesses and negative points of the company they are working in. It will surely influence the life of the company negatively. Worse is, hate speech is found in various social media [3]. Hate speech actually manipulates feelings and emotions, and this is used to manage people. As this kind of manipulation reaches a big scale, feelings, emotions, etc. play quite an important role nowadays.

\subsection{Managing people}

Managing people through hate speech, for example, is managing people in a negative way. It is not uncommon that there are almost always people who want to shine among the worst. By pointing out others' weaknesses and negative points, they think that they look better than others; this is actually shining among the worst, and it is not healthy. When it comes to companies, offices, and factories, that are related to jobs and work, managing people in a negative way like this can create unhealthy cliques and also lower productivity because when one's weak points or faults or mistakes or any negative aspects are exposed to others, feelings of dislikes and reluctance of working together in a team can inhibit the spirit of togetherness from achieving success. Teamwork becomes difficult, and success becomes farther away. 
Managing people should, therefore, be done in a positive way. In his book, WS [4] quotes Collin Powel, "Leadership is all about people. It is not about organizations. It is not about plans. It is not about strategies. It is all about people-motivating people to get the job done. You have to be people-centered." It means that in order of importance-people, organization (the group of people), and the plan which consists of strategies formulated together, people should come first. Even if one's weaknesses should be expressed, it should be done with a good purpose. This is especially true in dealing with a talented person. According to WS, a talented person is a person with a high altitude (high achiever), high aptitude (great ability), and a great attitude. The top management should be able to identify this kind of person for the sake of the company's progress. WS then says that the talented person should not be limited by regulations that will limit his or her actions because if s/he is not satisfied with her/his own development, s/he can move to another company. In this way, it is the company itself that does not get the benefit of having such a talented person. What one needs to do in managing people in an organization is actually making others develop themselves and give opportunities for them to reach their top point.

In order to make the people in the organization or the company can develop themselves, in his book, WS explains several formats of managing people and begins with the one that will not bring much progress for a company. The first format of development is the 1.0 format. In this format, there are no criteria. There is not any special program or reward for those who work better than others. All employees are treated the same, whether they achieve high or low. The 2.0 format is a little bit better. There are already some criteria, and who works better is already noticed. The 3.0 format is one step farther; it is not only the head of the unit which recognizes the talented person or people but also the head of other units. Special attention is already given for the talented people's development in their career. Even better than this one is the format of 4.0.

WS explains that the 4.0 format used in managing talented people can be done through the TEMPO approach. The first letter, T, stands for talent identification. He explains that a survey or discussion can be done among board directors, but the most important thing is their agreement on the criteria of a star. The criteria can be developed, and they should not be too simple or too complicated. The next letter, "E," is environment readiness, whether or not the company is ready to accept the leader of 4.0. The environment, the company or organization, should be prepared to accept the star as a leader. The environment that supports the star is the career path, the top management, system management and knowledge management. "M" stands for the mentoring program. "Expanding horizon is the mentor's duty so that a star can broaden his horizon. What a mentor can do is like what the word stands for: motivate, encourage, nurture, train, organize and reward. "P" represents the pilot testing field, and the last one, $\mathrm{O}$, is an opportunity to try new things, produce new concepts, and create breakthroughs.

In education, Intan [5] also has a format. In his talk, Intan says that education 1.0 was done on a one-to-one basis; the example given was an education carried out by a tutor for a prince. Although technology is now in 4.0, in dealing with people, what happened in 1.0 education should not be discarded. In the era of advanced technology like nowadays, it is easy to do something instantly for a lot of people. Announcements can simply be typed, and in just one second, lots of people can read the announcements. However, it is still important to communicate with people on a one-to-one basis. In managing people in the 4.0 era, oneto-one basis communication is still important. 


\subsection{Listening}

One-to-one basis of communication will indeed be useful when it is done in two directions. A good example about one-to-one basis of communication can be seen in the film on Susi Susanti [6]. Although there are so many badminton players in the training, the coach personally talks to Susi Susanti so that the expected result can happen. Susi Susanti's father also communicates to her on a one-to-one basis when he gives support to her daughter to continue the training in spite of her feeling homesick. Even the president talked to her on the phone to bring home the gold medal.

Communication is usually understood as speaking; the forgotten aspect is listening. The conversation between the Frog and the Rocket in Oscar Wilde's story [7] is a good example of communication or conversation. When the Frog bid goodbye and said that the Frog had enjoyed the conversation, the Rocket said that it was not a conversation. The Frog, then, answered that somebody must listen. The Frog also said that he liked to do the talking because it saved time and prevented arguments. Indeed, doing the talking only and letting the interlocutor listen prevent arguments, but that is not communication. This is passive listening. This is not the kind of listening and communication discussed in this article. The one which is important is active listening.

In managing people, active listening is very important. Active listening [8] has 'three parts: i) demonstrates moderate to high nonverbal involvement, ii) reflects the speaker's message using verbal paraphrasing, and iii) may include asking questions that encourage speakers to elaborate on his or her experiences'. Probably, the following experience can illustrate how listening is related to affective factors; this example explains the third part of active listening, namely: asking the speaker to elaborate on the experience. In a speaking class, a group of retakers occupied the whole class, and the students were known as the ones who played truant all the time. They were low achievers and unmotivated. Not wanting to waste her time for the whole semester, the teacher decided to set aside all the course outline and material on the first day, and the teacher asked them to speak about themselves why they could be low achievers and were often absent in the previous class. One by one talked about the reasons and why they were there studying in the English Department.

Not one of the students actually wanted to study English, and they had their own ideals to pursue in life. After all of them finished speaking, the teacher asked them the second question: "Now that you are here, what can your study enhance what you want to achieve?" No one answered. The teacher began to call the name of one of them and made the question more specifically to their own situation. For example, to the girl who wanted to open a boutique, she asked, "How can English be useful for your boutique business? She began to answer her question in detail. The teacher asked for an elaboration to each of the ten students until all of them found their purpose to study there. The students in that class did not suddenly change from $\mathrm{C}$ students to A students. No. However, at least, all of them passed the class, improved their scores a little bit, and the most important thing was that they were never absent, even once, until the end of the semester. One might argue that it is not caused by listening, but by giving them motivation and showing the purpose of what they were doing at that time when they thought it was against their will. That is right, but it started with the action of listening.

Another example which occurred in a factory was told by a speaker at a conference and is related to the first part of active listening, that is non verbal involvement. A worker in a factory told the supervisor that the lamp was not bright enough in her lane. The supervisor did not only listen, but also did something. The supervisor changed the light bulb and making the story short; the production increased. In fact, the brightness of the light bulb 
changed was not that significant. The explanation is that the factory worker felt that she was listened to, and this influenced her performance. Listening can increase the engagement of the person listened to. One importance of listening to employees, other than making them feel respected as human beings, is to prevent the people who work there to use social media as a place to pour one's heart content.

However, one needs to choose what one should listen to. Constructive criticism, which is scientifically studied involving the emotions associated with receiving feedback [9], positive suggestion, and evaluation for the sake of better management and achievement, should be paid attention to, but anything that finds faults of others forms cliques and therefore, should be filtered. The writer cannot agree more with Icks and Shiraev [10] that "attacking someone's name and reputation is about tickling a receptive audience's imagination' and 'across countries and time, people have used images and words to harm, devastate, and completely destroy other people's reputation, status, and character. Characater assassination still does happen until now, either in a big or small scale. People might no realize that it happens in their own office, schools, or companies. There are people who are clever in telling details about others' weaknesses or sins that can directly change the hero in the listener's imagination into the garbage of society. One needs to choose what should be given a response. If not, productivity will be lowered and a lot of time will be wasted to deal with unimportant issues. One should dare to throw away any negative content that one hears.

\section{Conclusion}

Although technology has developed greatly and education is in the era of the internet of things, managing people still needs to be done on a one-to-one basis. After all, human beings have hearts, and all the affective factors--emotion, feelings, needs, motives, attitude-are related to the hearts. It is the heart that makes people human, and therefore, it is important to pay attention to it. Listening can be one of the ways that can make people feel human. Managing people should be done with a good purpose in mind so that people can shine among the best and the company can have good progress.

\section{References}

1. Haryatmoko. Disrupsi [Disruption]. Paper presented in [General Lecture] at Airlangga University Surabaya, (Surabaya, Indonesia, 16 May 2019). [Online unpublished]. [in Bahasa Indonesia].

2. P.M. Lightbown, N. Spada. How Languages Are Learned, Oxford: Oxford University Press. (2013).

https://books.google.co.id/books/about/How_Languages_are_Learned_4th_edition_O x.html?id=5PadBgAAQBAJ\&redir esc $=y$

3. B.M. Ratmono. Media baru dan kerahasiaan negara, [New media and state secrecy]. Paper presented in Seminar Nasional: Media Baru, Budaya, Politik, dan Agama. (Yogyakarta, Indonesia, 15 August 2019). [in Bahasa Indonesia]. https://seruindonesia.com/2019/06/19/media-baru-budaya-politik-dan-agama/

4. P.B. WS. As CEO's soulmate. Jakarta: PT Elex Media Komputindo (2014). [in Bahasa Indonesia]. https://opac.perpusnas.go.id/DetailOpac.aspx?id=913815

5. R. Intan. Peluang dan tantangan perguruan tinggi di era industry 4.0. [Opportunities and challenges of tertiary institutions in the industrial era 4.0.]. Paper presented in Workshop Outcome Based Education (OBE) dan Keterkaitan dengan ASEAN University Network Quality Assurance (AUN-QA), (Surabaya, 3-5, July 2019). [in 
Bahasa Indonesia]. http://dwipekan.petra.ac.id/2019/07/23/outcome-based-educationuntuk-menghasilkan-pendidikan-yang-sesuai-dengan-zaman/

6. F. Sim, Susi Susanti: Love All, [Biography], Damn! I Love Indonesian Movies: Indonesia (2019). [in Bahasa Indonesia]. https://www.imdb.com/title/tt10394822/

7. P. Moy. Journal of Communication, 70,1:1-12(2020). https://doi.org/10.1093/joc/jqz049

8. H. Weger, G.C. Bell, E.M. Minei, M.C. Robinson. International Journal of Listening, 28,1:13-31(2014). https://doi.org/10.1080/10904018.2013.813234

9. C.J. Fong, D.L. Schallert, K.M. Williams, Z.H. Williamson, J.R. Warner, S.Lin. Y.W. Kim. Thinking Skills and Creativity, 30:42-53(2018).

https://www.sciencedirect.com/science/article/abs/pii/S1871187117301529

10. M. Icks, E. Shiraev. Character Assassination throughout the Ages. New York:

Palgrave Macmillan (2014).

https://link.springer.com/chapter/10.1057/9781137344168_1 